\title{
SOCIO-ECONOMIC CONTRIBUTIONS OF SMALL-SCALE PLANTATIONS IN ETHIOPIA
}

\author{
Yilebes Addisu Damtie*, Mandefrot Amare ** \\ * Bahir Dar University, Institute of Disaster Risk Management and Food Security Studies, Bahir Dar, \\ Ethiopia \\ ** Gambella University, Department of Agro-economics, Gamebella, Ethiopia
}

corresponding author: Yilebes Addisu Damtie, e-mail: yileaaddisu@gmail.com

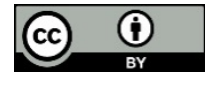

This work is licensed under a

Creative Commons Attribution 4.0

$\underline{\text { International License }}$
Professional paper

Received: May $3^{\text {rd }}, 2019$

Accepted: July 22 2019

HAE- 1913

https://doi.org/10.33765/thate.9.4.3

\begin{abstract}
In order to enhance the attention given by farmers, government and concerned bodies, the socioeconomic contributions of small-scale plantations should be studied. This study identified the socioeconomic benefits of small-scale plantations in the Godera Woreda of Gambella Region, Ethiopia. Data were collected through questioners and key informant interviews from 208 farmers and 8 key informants. Descriptive statistics and a regression model were used to analyse the data. The results of the study revealed that of the average 1.72 ha of land possessed by small-scale farmers 0.81 ha was used for tree plantations. The main types of plantations were coffee, eucalyptus, banana and avocado. The mean annual production was $645 \mathrm{~kg}, 290 \mathrm{~kg}$ and $271 \mathrm{~kg}$ for coffee, banana and avocado, respectively. Small-scale farmers earned a mean of 4675.56 Birr $^{1}$ from plantations which was $32.37 \%$ of the total income. The Woreda government gained 365,022 Birr royalty payment during 2015/16.The regression results show income from plantations significantly affects the annual income of small-scale farmers $(\beta=0.436, p<0.01)$. Access to basic services, land use change, expenditures, population growth, employment opportunities, and migration are social changes supported by small-scale plantations. The availability of a favourable environment, extension service, land, and peace are opportunities of plantations. In contrast, challenges of small-scale plantations are disease, low prices for product, lack of improved plantation varieties, shortage of land, lack of demand, climate change and rainfall reduction, lack of government support, and high transportation costs. It is recommended to strengthen the small-scale plantations for better positive socio-economic contributions of the sector through supporting the opportunities and management of identified challenges.
\end{abstract}

Keywords: plantations, small-scale farmers, contributions

\footnotetext{
${ }^{1} 1 \mathrm{USD}=23.09$ Birr
} 


\section{INTRODUCTION}

\section{Statement of the problem}

Currently, the world is facing land use changes which are governed by human interventions and causing usually clearing of forests. Such changes are found guilty of influencing disastrous events of climate change, drought and flood among others. The continuing rate of deforestation and the weakness of conventional forest protection practices made look out for a more promising strategy [1]. The plantation products should be accessed in a responsible manner and they should be protected from over-exploitation [2].

Forest associated problems such as forest conversion, biodiversity loss, and local environmental change have aroused widespread attention throughout the world. Similar processes are occurring in Ethiopia. With taking consideration of these problems some national efforts are undergone. Among these national natural resource conservation gained adequate consideration.

Even though the Ethiopian government is supporting natural resource conservation works, most of the works are on communal lands of the society. In order to achieve the green resilient economy and improve the natural resources of the country, land at the hand of small-scale farmers must contribute. Plantations on small-scale farmers land are based on farmers' interest and the government intervention is not as such bigger. Thus, there is a need to disclose the socio-economic contributions of plantations and convince small-scale farmers to practice plantations and not to clear and shift existing privately owned plantations area for other purposes. Also, the government should acknowledge the contributions and support small-scale plantations.

The need to have sound information to support policy development for small-scale forestry can be expected to intensify the practice. Socio-economic analysis of forestry system has been a neglected research area. There is a severe lack of information about the plantations. Small-scale plantations face a large number of constraints and present a wide variety of policy issues [3].

Plantations should have a thorough assessment [4]. Socio-economic contributions assessment which is an assessment of the outcomes of plantations for the people is very important to show the government, concerned bodies and small-scale farmers about the importance of small-scale plantations.

\section{Objectives of the study}

The objectives of the study are:

- to assess the plantations status of the area,

- to identify socio-economic contributions of small-scale plantations and

- to examine the challenges and opportunities of the small-scale plantations in Godere Woreda of Gambella region, Ethiopia.

\section{Definition of terms}

Plantation: the term plantations in this study cover trees and perennial crops owned by the small-scale farmers.

Small-scale farmers: defined as farm households that own and cultivate less than 2.0 ha of agricultural land.

\section{METHODOLOGY}

\section{Description of the study area}

Gambella is the regional state in Ethiopia with three administrative zones (Nuer, Anuak and Mejeng). The Mejeng zone is the smallest and less populous zone in the region located in the South-eastern part of the state bordering Gambella with Southern Nations, Nationalities and Peoples. There are two Woredas in the Mejeng zone which are Godere and Mengesh. The main nationalities of the Woreda are Majeneg. Moreover, the Oromo, Amhara, Kembta, Keffa, Tigray and other nations and 
nationalities live in the Woreda. The study was conducted by taking one representative Woreda from the Mejeng Zone of the region. Godere Woreda was an area of the study. Based on the survey of 2007, the population of the Woreda was 38763 [5].

\section{Research design}

Mixed research design was used for this study. More specifically, a survey designed from the quantitative approach was used. In addition, qualitative data was used to substantiate and complement the findings obtained via the quantitative survey. Generally, the researchers used questionnaires and key informant interviews as a tool of data collection.

The number of survey participants was 208 small-scale farmers and eight key informants were interviewed. The sample households selected proportionally from four kebeles of the Woreda namely Toil and Tokali, Sumuy, Chemie, and Mehakelegaw Meti.

Data of the study was analysed through descriptive statistics and simple regression model. Descriptive statistics was computed to analyse the demographic situation and the social contributions of small-scale plantations. In order to understand the economic contributions of small-scale plantations, regression model was used. The data was analysed by Microsoft Excel and SPSS.

Identifying socio-economic contributions of plantations is challenging. It is usual for multiple changes to be occurring simultaneously, of which small-scale plantations takes only some part [6]. The study tried to identify the contributions of smallscale plantations on the changes observed. Impact/contribution is conceived as anything that affects or concerns any stakeholder group directly or indirectly [7]. The social contributions of small-scale plantations were assessed by open-ended social status indicator variables. For the case of economic contribution analysis land price, significance of plantations on the households' total income and royalty payment was used.

A simple regression model was selected and used to show the significance of households' plantations coverage on the total income of small-scale farmers. The mean annual income of the households from all sources was the dependent variable of the model. The annual income of the households from each source was summed to come up with an annual income of the households. This variable was continuous and measured by Birr. The independent variable, households' plantation coverage, measured in hectare and it was hypothesized to affect the total annual income of households. The formal equation of simple regression model can be expressed as

$$
\mathrm{Y}_{\mathrm{i}}=\beta_{o}+B_{i} \cdot \mathrm{X}_{1}+\varepsilon_{\mathrm{i}}
$$

where:

$\mathrm{Y}_{\mathrm{i}}$ - represents the dependent variable which is total income of households in this case,

$\beta_{o}$ - is the constant term,

$X_{1}$ - denote the explanatory variable or plantations in hectare,

$B_{i}$ - is the coefficient associated with explanatory variable and

$\varepsilon_{\mathrm{i}}$ - is the observable random error term or disturbance.

\section{RESULTS AND DISCUSSION}

\section{Household characteristics}

The sample households were from eight different nations; Oromo (30.3\%), Amhara (28.9\%), Mejeng (24.5\%), Kefa $(8.7 \%)$, Bench (6.3\%), Sheka (1\%), Sheko (0.5\%), and Tigra $(6.3 \%)$. Mean age of sample household heads was 41.94 years ranging from 17 to 90 years of age. The mean educational attainment of sample household heads was 4.36 years. 


\section{Landholding and land cover}

The study tried to see the land holding and land cover of small-scale farmers. The results showed that the sample household's possessed a mean of 1.72 ha of land and plantations taken the leading in terms of land cover. Approximately 0.81 ha of land which takes $47.09 \%$ of the total was vested for the plantations followed by 0.59 ha of land for crop production (Figure 1). In contrast, only 0.03 ha of land was left for grazing (Figure 1).

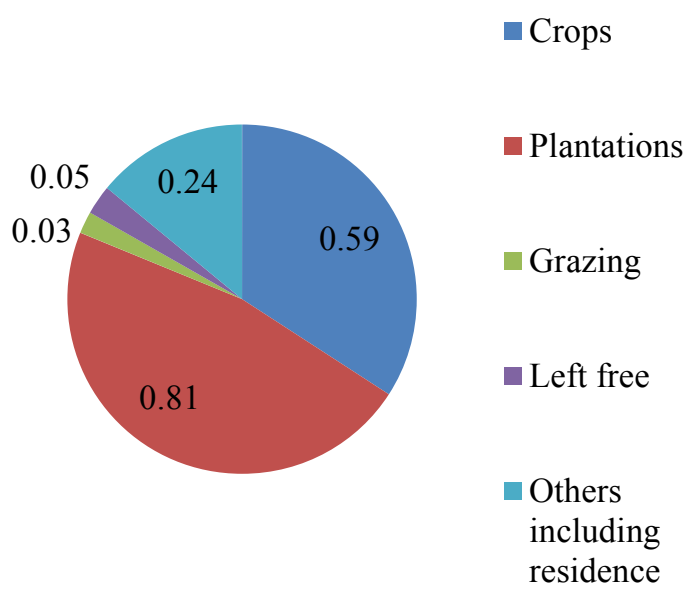

Figure 1. Mean land holding and cover of small-scale farmers in hectare $(n=208)$

\section{Plantations and their production}

Despite the sample households were selected randomly all of them were plantations practitioners with an average experience of 16 years ranging from 2 up to 70 years in smallscale plantations. The key informant interviews and the survey results revealed the suitability of climatic and agro-ecological conditions of the area for small-scale plantations rather than crop and animal productions. The main types of plantation trees were coffee, eucalyptus, avocado and banana. On average 0.71 ha of coffee plantation trees was owned by small-scale farmers. As depicted in Table 1 the mean annual plantations production was high for coffee $(645 \mathrm{~kg})$, banana $(290 \mathrm{~kg})$ and avocado (271 $\mathrm{kg}$ ) as compared to others.
Table 1. Plantations and annual production $(\mathrm{n}=208)$

\begin{tabular}{|c|c|c|}
\hline $\begin{array}{c}\text { Plantation } \\
\text { type }\end{array}$ & $\begin{array}{c}\text { Number of } \\
\text { plantation trees } \\
\text { owned }\end{array}$ & $\begin{array}{c}\text { Annual } \\
\text { production in } \mathrm{kg}\end{array}$ \\
\hline Mango & 2.43 & 107.83 \\
\hline Coffee & 0.71 ha & 645.81 \\
\hline Papaya & 2.52 & 21.99 \\
\hline Eucalyptus & 138.98 & \\
\hline $\begin{array}{c}\text { Cordia } \\
\text { Africana }\end{array}$ & 3.38 & \\
\hline Avocado & 5.72 & 271.68 \\
\hline Banana & 24.78 & 290.22 \\
\hline Others & 25.68 & 17.09 \\
\hline Coffee in terms of hectare, the rest in terms of tree
\end{tabular}

\section{Economic contributions of small-scale plantations}

Plantations and their products can be used for food, charcoal, fuel wood and construction. The survey participants were asked about the usage of the plantations products. The quantitative results showed the farmers income gained from the plantations. The sample smallscale farmers gained a mean annual income of 4675.56 Birr from small-scale plantations. Sale of the plantations for food has taken the biggest share of income from the sector. A mean of 4473.01 Birr per household per annum was found from selling of plantations for food and the contribution of coffee was enormous in this regard. Selling plantation for construction was the other income source and it created a mean of 185.96 Birr annual income per household. Unlike some rural parts of Ethiopia, no income was found from selling of charcoal and fuel woods. The survey and key informant interviews revealed that selling of charcoal and fuel woods are not common in the area.

Plantations were the second larger income source of the small-scale farmers. An income of 4675.56 Birr from 14442.51 Birr annual total annual income was gained from smallscale plantation. In terms of percentage, it covered 32.37 percent of the annual income. The sample households gained a mean annual income of 5895.37 Birr from farm income, 
151.88 Birr from off-farm and 3719.71 Birr from non-farm sources.

The other indicator of the economic contributions of small-scale plantations was the land prices change. The Ethiopian government declared that land is the possession of the government and selling of land is illegal. But the people have the right to use and develop the land they hold. However, there are still some selling of land through different mechanisms. Because of the increasing benefit of plantations and interest of widening plantation areas, land prices were raising and it was reported by $78.8 \%$ of respondents. Only $5.8 \%$ households believed that the land prices were the same and the rest $15.4 \%$ reported the decreasing trend of land prices.

The other economic benefit of plantations was royalty payment. A royalty is a payment for the right to ongoing use of an asset. Royalties can be stated as a percentage of gross or net revenues derived from the use of an asset or a fixed price per unit sold of an asset. The Ethiopian government has declared the royalty payment on federal income tax proclamation No. 979/2016. Tax on royalties is a flat rate of five percent $(5 \%)$ both for a resident of Ethiopia and a non-resident who derives an
Ethiopian source royalty [8]. Based on this declaration, Godera Woreda government collected royalty payment on timber and furniture products taken out of the Woreda. During the study year 2015/16, the Woreda had collected around 365,022 Birr from royalty payment.

In addition, regression model was used to assess the significance of small-scale plantations for total annual income of smallscale farmers. As a result, the outcomes of the model analysis were quite relevant and indicative of the existing reality.

As revealed in Table 2, income from plantations was found with significant contribution on determining the annual income of small-scale plantation farmers. Income from plantations was found significant at less than $1 \%$ probability level. This results show the strong contribution of a plantations for the farmers' income.

The percentage share of income and the significance of plantations coverage of households on the annual income of households revealed the economic contribution of small-scale plantations. In addition, the royalty payment was one good income source for the Woreda.

Table 2. Simple regression estimates of annual households income $(n=208)$

\begin{tabular}{|c|c|c|c|c|c|c|}
\hline \multirow{2}{*}{\multicolumn{2}{|c|}{ Variables }} & \multicolumn{2}{|c|}{$\begin{array}{l}\text { Unstandardized } \\
\text { coefficients }\end{array}$} & \multirow{3}{*}{$\begin{array}{c}\begin{array}{c}\text { Standardized } \\
\text { coefficients }\end{array} \\
\text { Beta } \\
\end{array}$} & \multirow[t]{2}{*}{$\mathrm{t}$} & \multirow[t]{2}{*}{ Sig. } \\
\hline & & B & Std. Error & & & \\
\hline \multirow[b]{2}{*}{1} & (Constant) & 613.668 & 5033.068 & & 0.122 & 0.903 \\
\hline & $\begin{array}{c}\text { Area covered } \\
\text { by plantations }\end{array}$ & 13289.337 & 3572.486 & 0.436 & $3.72^{* * *}$ & 0.000 \\
\hline \multicolumn{7}{|c|}{$\mathrm{R}^{2}=0.436, \Delta \mathrm{R}^{2}=0.190$} \\
\hline
\end{tabular}

\section{Social contributions of small-scale plantations}

Even though small-scale plantations are not the sole case for the social changes occurred in the area, the study tried to identify the contribution of plantations created on social aspects. For analysis of social changes, openended social variables were selected. The results disclose the occurring changes due to the availability of small-scale plantations. The specific social changes supported by the smallscale plantations are stated below.

Access to basic services was improved a lot 
due to small-scale plantations. Survey and key informant interviews revealed the improvements of services like water, light, road, school, and market centers. For the transportation of plantations products roads were constructed even to some small villages of the Woreda. As the production and demand of plantations were rising; the merchants' interest to transport the products to the central markets in the region and country was increasing. Following this, the government and community constructed all weather and dry season roads. Local markets were established and improved for the transaction of plantations products. Some of the social contributions come after the economic contributions of the plantations.

The economic development of small-scale farmers helped them to spend some cost and access better school, water, light, and other sources. As the farmers got good income from plantations products, their expenditure trend for the inputs and consumption improved a lot. The increasing trend of expenditure was shown on $56.7 \%$ of respondents (Figure 2).

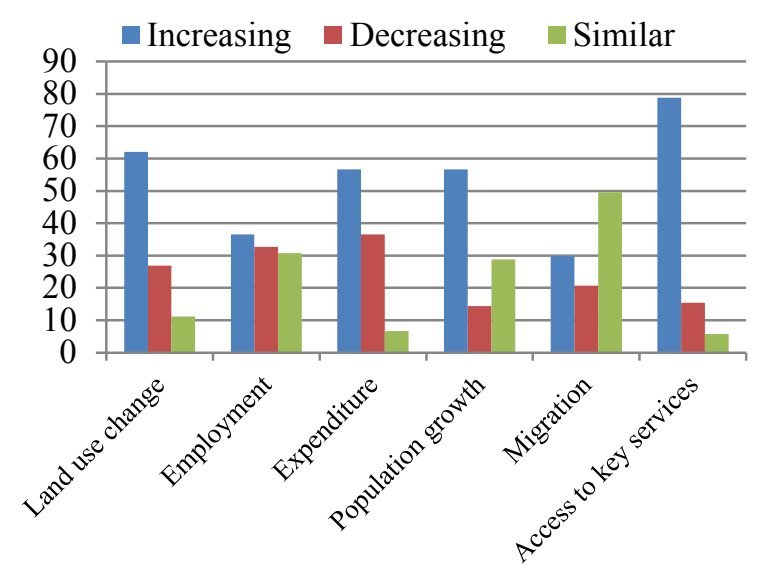

Figure 2. Social contributions of small-scale plantations in percent $(n=208)$

The other interrelated social changes were population growth, employment, and migration. The population of the area was increasing a lot due to the high birth rate. Like the rest of the country, the birth rate of the area was high and it contributed to the population growth. Even if the birth rate was the main factor for the increment of the population, plantations had some contribution through different ways. Income from plantations helped farmers to meet the need of the family and to extend their family size and access health centers.

Migration also played for population growth as people immigrate to the area for permanent and temporal settlement. The ethnic/nation background of respondents could support this truth. The host nations of the area were Mejeng people; however, eight different nations participated as a respondent. Most of these people come as a migrant. These people were permanent settlers of the area and attracted by small-scale plantations while there were some others with the temporary stay as an employed labour. The temporary employee shared in the small-scale plantations mostly for the collection of products. Such an employment was famous for coffee gathering. The share of employment had decreased to a quarter of a production from half a production starting from the last two years. Because of the reduction of share from temporary employment, the number of temporary migrants was decreasing. Especially, those coming from other areas of the country were decreasing.

The land use change was also one of the changes in the area. It was reported that farmers were shifting their land to a plantations. Because of the increased price of plantations products; farmers of the area were convinced to shift their land mainly the crop production, grazing and communal lands into plantations. Around $62 \%$ of the respondents confirmed the increasing pattern of land use change (Figure 2).

In addition, social groups were established for the better opportunities of small-scale farmers. Small-scale farmers in the Woreda organized unions for the facilitation of the selling products and purchasing of inputs. Especially coffee unions were usual social groups in the area. 


\section{Challenges and opportunities of small-scale plantations}

After the analysis of socio-economic contributions, it is necessary to assess the challenges and opportunities of the small-scale plantations for further development and extension works. Based on this open-ended choices were given for respondent households to come up with the purpose.

The survey result shows the favourability of the environment for plantations. Naturally, the area has a good temperature and rainfall which are very supportive for the plantations. The existence of extension service $(60.7 \%)$, land $(39.9 \%)$, and peace $(15 \%)$ were the other opportunities available for small-scale plantations (Figure 3).

The major challenge of the small-scale plantations is the existence of the diseases. Diseases are highly existent on fruit plantations of the area especially coffee, avocado, mango, orange and banana plantations were highly vulnerable to the disease. Diseases affect plantations of $95 \%$ respondent farmers (Figure 4). The key informants revealed that less emphasis is given for the management of the diseases and even the types of the diseases affecting the tree plantations are not well studied.

The second most important challenge is the low prices for the plantations. Since the people of the area produce similar types of products, the demand for the products is limited and the prices offered for products are low as compared to other areas of the region and the country in general. The unfair, low prices for plantations are shown by $89.4 \%$ of respondents (Figure 4).

The other challenge of small-scale plantations is lack of improved seed varieties. The plantation varieties of the area are susceptible to the diseases and there is a need of disease resistance varieties which are not answered by the agricultural office and its partners. In addition, there is a shortage of land in the area. Following the migration of farmers and investors to the area, the possibility of having additional land for the plantations was limited.

Even though there are some opportunities for plantation sector, it is also facing many challenges which hinder the progress and development of small-scale plantations.

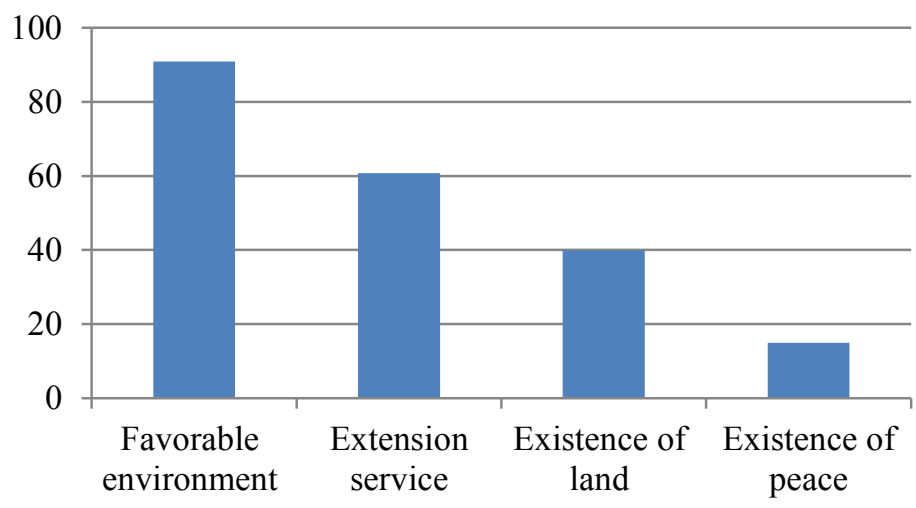

Figure 3. Opportunities of small-scale plantations in percent $(n=208)$ 


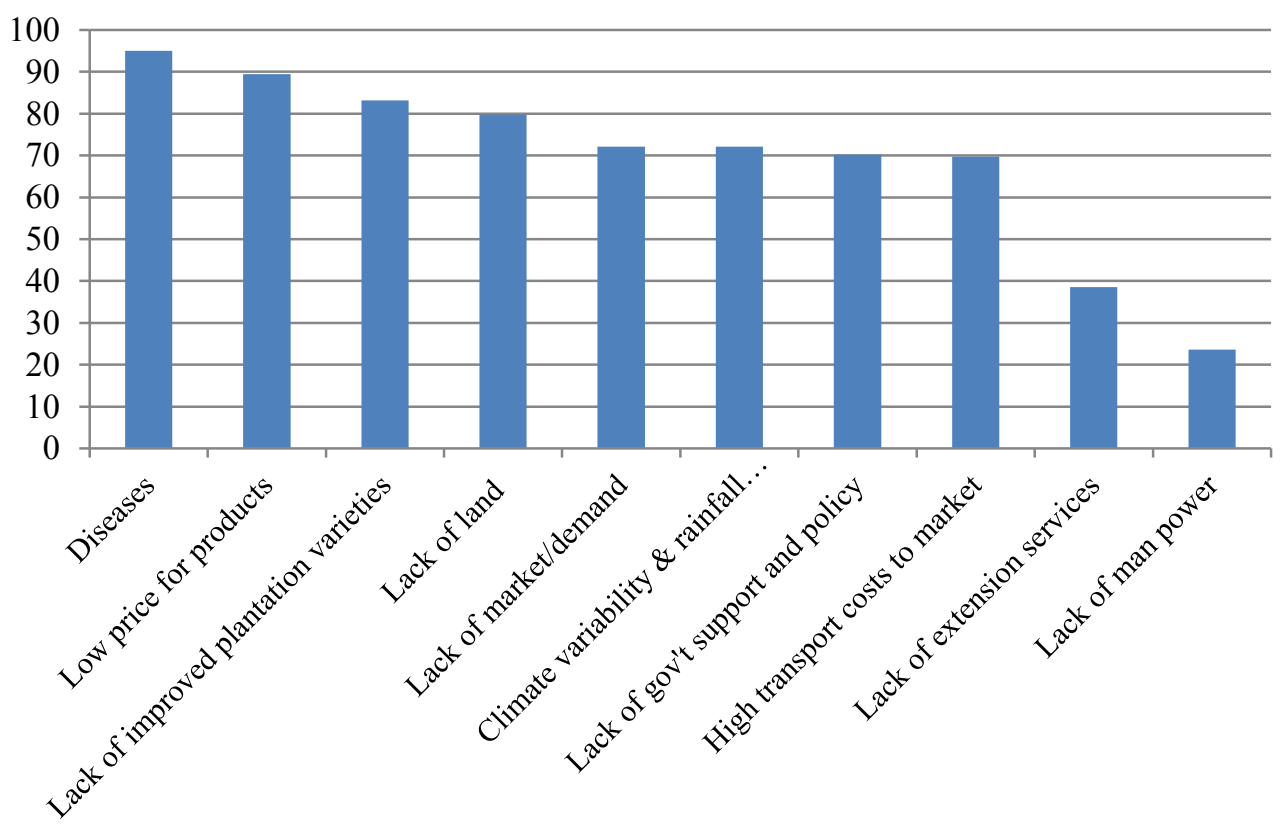

Figure 4. Challenges of small-scale plantations in percent $(n=208)$

\section{CONCLUSION}

The study was aimed to assess the socioeconomic contributions of small-scale plantations in Godera Woreda of Gambella region, Ethiopia.

Small-scale farmers employ 0.81 ha or 47.09 $\%$ of their land for tree plantations. Coffee, eucalyptus, banana and avocado are the dominant plantations in terms of coverage and production. The mean annual production was $645 \mathrm{~kg}$ for coffee, $290 \mathrm{~kg}$ for banana and 271 $\mathrm{kg}$ for avocado.

Small-scale farmers gained a mean of 4675.56 Birr which is $32.37 \%$ of their income and the Woreda government collected 365,022 Birr royalty income per annum from plantations. Plantations coverage significantly contributions for total annual income of smallscale farmers $(\beta=0.436, p<0.01)$. Also, the land price has increased from the previous years.

Social status changes are also strongly supported by small-scale plantations. The major social changes observed due to the existence of small-scale plantations are access to basic services, land use change, expenditure, and population growth.

Finally, the study investigates challenges and opportunities of small-scale plantations. Opportunities of the plantations are the existence of favourable environment, extension service, land, and peace. The most important challenges of the plantations are diseases, low prices for products, lack of improved varieties, shortage of land, lack of demand, climate variability and rainfall reduction, lack of government support, and high transportation cost in descending order.

The small-scale plantations should be supported for a better outcome of the smallscale plantations by the government and concerned bodies. Thus, strengthening of opportunities and management of challenges is crucial. Some of the challenges need urgent solutions; the management of diseases, provision of improved plantation varieties and better market opportunities and prices for products should be urgent intervention areas. Further studies on the types of plantations diseases and their management are recommended for the coming researchers and academicians. 


\section{REFERENCES}

[1] Z. Getu, Socio-economic and environmental impact assessment of devolution of natural resource management in Adaba-Dodola forest area, MSc. Thesis, Alemaya University, 2005.

[2] T. Terefe, Effects of participatory forest management on the socio-economic conditions of the local communities with special reference to the forest dwellers associations in Adaba-Dodola forest priority Area, MSc Thesis presented to Swedish University of agricultural sciences, Sweden, 2002.

[3] S. Harrison, Research approaches to environmental-economic issues in smallscale forestry, Proceedings book of International IUFRO Symposium, Economic Sustainability of Small-Scale Forestry, eds.: A. Niskanen, J. Väyrynen, European Forest Institute, Finland, 2001, 201-214.

https://www.iufro.org > download > file > 30800-joensuu01-proceedings pdf

Accessed: September 12, 2016.

[4] WWF International, Ecosystem integrity and forest plantations: New generation plantations project, Technical Paper, 2009.

https://newgenerationplantations.org/mul timedia/file/3ab82968-74a2-11e3-92fa005056986313

Accessed: September 12, 2016.

[5] Central Statistical Agency, Summary and statistical report of the 2007 population and housing census, Population size by age and sex, Addis Ababa, Ethiopia, 2008.

https://www.ethiopianreview.com/pdf/001/C en2007 firstdraft(1).pdf

Accessed: September 12, 2016.

[6] J. Schirmer, Socio-economic impacts of land use change to plantation forestry: A review of current knowledge and case studies of Australian experience; School of resources, environment and society Australian national University, ACT and cooperative research center for forestry, Hobart, 2005. http://citeseerx.ist.psu.edu/viewdoc/dow nload?doi $=10.1 .1 .424 .3682 \& \mathrm{rep}=\mathrm{rep} 1 \& \mathrm{t}$ ype $=$ pdf

Accessed: September 12, 2016.

[7] International Association for Impact Assessment (IAIA), Social impact assessment: Guidance for assessing and managing the social impacts of projects, 2015.

https://www.iaia.org/uploads/pdf/SIA_G uidance Document IAIA.pdf

Accessed: September 12, 2016.

[8] Merkato. Tax on royalty payment in Ethiopia,

http://www.2merkato.com /articles /tax/types/1005-tax-on-royaltypayments-in-ethiopia, Accessed: September 12, 2016.

\section{Acknowledgements}

The authors acknowledge Gambella University for funding this study. 